\title{
Foreign direct investment through acquisitions and implications for technological upgrading: Case evidence from Tanzania
}

Citation for published version (APA):

Portelli, B., \& Narula, R. (2004). Foreign direct investment through acquisitions and implications for technological upgrading: Case evidence from Tanzania. MERIT, Maastricht Economic Research Institute on Innovation and Technology. MERIT-Infonomics Research Memorandum Series No. 008 https://doi.org/10.26481/umamer.2004008

Document status and date:

Published: 01/01/2004

DOI:

10.26481/umamer.2004008

Document Version:

Publisher's PDF, also known as Version of record

Please check the document version of this publication:

- A submitted manuscript is the version of the article upon submission and before peer-review. There can be important differences between the submitted version and the official published version of record.

People interested in the research are advised to contact the author for the final version of the publication, or visit the DOI to the publisher's website.

- The final author version and the galley proof are versions of the publication after peer review.

- The final published version features the final layout of the paper including the volume, issue and page numbers.

Link to publication

\footnotetext{
General rights rights.

- You may freely distribute the URL identifying the publication in the public portal. please follow below link for the End User Agreement:

www.umlib.nl/taverne-license

Take down policy

If you believe that this document breaches copyright please contact us at:

repository@maastrichtuniversity.nl

providing details and we will investigate your claim.
}

Copyright and moral rights for the publications made accessible in the public portal are retained by the authors and/or other copyright owners and it is a condition of accessing publications that users recognise and abide by the legal requirements associated with these

- Users may download and print one copy of any publication from the public portal for the purpose of private study or research.

- You may not further distribute the material or use it for any profit-making activity or commercial gain

If the publication is distributed under the terms of Article $25 \mathrm{fa}$ of the Dutch Copyright Act, indicated by the "Taverne" license above, 


\section{MERIT-Infonomics Research Memorandum series}

Foreign direct investment through acquisitions and implications for technological upgrading:

Case evidence from Tanzania

Brian Portelli \& Rajneesh Narula

2004-008

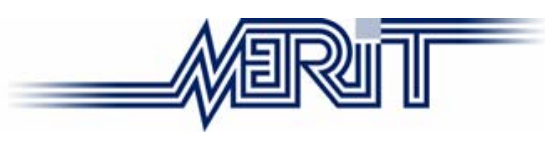

MERIT - Maastricht Economic Research Institute on Innovation and Technology

PO Box 616

6200 MD Maastricht

The Netherlands

$\mathrm{T}:+31433883875$

F: +31 433884905

http://www.merit.unimaas.nl

e-mail:secr-merit@merit.unimaas.nl

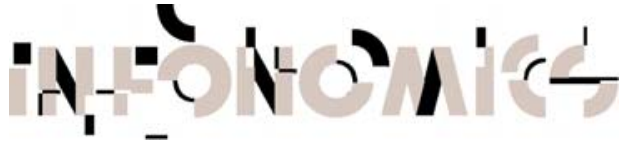

International Institute of Infonomics

c/o Maastricht University

PO Box 616

6200 MD Maastricht

The Netherlands

T: +31433883875

F: +31 453884905

http://www.infonomics.nl

e-mail: secr@infonomics.nl 


\title{
Foreign direct investment through acquisitions and implications for technological upgrading: Case evidence from Tanzania
}

\author{
Brian Portelli and Rajneesh Narula
}

\begin{abstract}
Using a case-study approach, this study examines the role of privatisation on the industrial landscape of Tanzania. We examine the impact of FDI through acquisitions on technology transfer within the acquired firm as well as the development of linkages to other firms based in the host country. Our results suggest that technological upgrading has occurred following FDI, the intensity of which reflects the type of firm-specific assets of parent MNE, as well as the pre-acquisition state of these industrial activities. Improved backward linkages are also evident with local economic agents, but their type and extent - reflecting Tanzania's comparative advantage in the primary sector - confirm that capabilities both within the acquired firms and also in the industrial base of the host country greatly influence the magnitude and intensity of technological upgrading. 'Narrower' technology gaps between the MNE affiliate and the domestic sector are more likely to result in backward linkages and determine the type of technological content of inputs sourced locally rather than within the MNE.
\end{abstract}

\section{Introduction}

This article seeks to contribute to our understanding of the implications of FDI on the upgrading prospects of host developing countries, based on primary research through case studies of FDI through privatisation in Tanzania. It is generally accepted from a developmental perspective that FDI flows are crucial because they represent an important source for technological spillovers in the host country.

In developing countries, structural adjustment programmes prominently integrate macroeconomic stabilization policies alongside policies to promote increased inward FDI. The most important element of these programmes is economic liberalization and the divestiture of state-owned industrial concerns. Particularly in the least developed economies,

such as those in Sub Saharan Africa (SSA), the scope for FDI has increased in the context of government liberalisation and privatisation programmes (Lall 2002, Pigato 2001). Although not the only means available, FDI spillovers are regarded as one of the most practical and efficient means by which industrial development and upgrading can be promoted (Narula and Dunning 2000). It is argued that FDI potentially increases the rate of technical progress in the host country through a 'contagion' effect from the application of more advanced technology 
and management practices used by foreign affiliates on to other host based firms (Findlay 1978). Most notable of these externalities is the potential contribution of FDI to the industrial and technological upgrading in the host country or efficiency spillovers starting from the industrial set-ups they acquire.

The focus in this paper is on two inter-related aspects of the potential FDI-led upgrading process in a developing country. The first focus is on the impact of FDI on technology transfer or absorption in new acquired enterprises, i.e. within the acquired firm, as a result of the technology and knowledge transferred from the acquirer. The second focus is on the potential of technology spillover in the host country through vertical backward linkages, i.e. with other firms based in the host country ${ }^{1}$. An analysis of local value chain of MNE affiliates is not enough to inform us on the potential for technology spillovers in the host country Per se. Backward linkages also serve as a conduit for MNE technology spillovers. However it is not the scope of the present paper to analyse the type of knowledge transfer through linkages, but only to explore the potential for these spillovers to occur.

The empirical evidence presented in this paper is based on primary data on FDI activity in Tanzania. Tanzania represents a typical case of a developing country that has been undergoing an extensive economic liberalization process. Privatisation of state-ownedenterprises represents a major pull factor for FDI inflows ${ }^{2}$. The only empirical evidence from Tanzania pertains to the macro impact of acquisitions (Mbelle and Shitundu 1999, Mwandenga 2000). Little has been written on the process of FDI-led industrial upgrading and technological development both within the affiliate and through linkages with host-based firms.

The rest of the paper is organised as follows. First, we review the literature and empirical evidence on the impact of FDI through M\&As in host developing countries and on MNE linkages and spillovers with reference to their respective determinants. Next, we use this theoretical framework to inform our research propositions. After a brief description of the research methodology, we present two cases of FDI through acquisition in Tanzania and after that the main findings pertaining to our study. The final section presents some conclusions and policy implications.

\section{Background and review of relevant literature}

The increase in privatisation related FDI is reflected in the rise of foreign exchange revenues from privatisation deals which increased from 1.1 billion US dollars in 1991-1994 period to 3.2 billion US dollars in 1995-1998 period ${ }^{3}$. During the 1990s, FDI represented 
about 60 per cent of foreign exchange raised in all developing regions and a higher proportion of 80 per cent in Sub Saharan Africa (SSA). In an important study, Liberatori and Pigato (2000) show that between 1990 and 1998, approximately 14 per cent of FDI was privatization related. In particular, the increase in privatisation-related FDI has nurtured cross-border acquisitions in SSA. Between 1997 and 1999, almost 40 per cent of FDI inflows into Africa came in the form of cross-border M\&As. On a global scale, however, Africa's share in cross border M\&As is negligible at less than 0.5 per cent in 1999 (UNCTAD 2000) reflecting the fact that very few domestic enterprises possess firm-specific assets - for example in the form of new technologies, well-known brand names or strong presence in attractive markets that could make them interesting targets for a take-over by foreign firms.

FDI represents a "combination of capital, stock, know-how and technology" (De Mello 1997). Host countries increasingly view FDI as a potential source of bridging the gaps in their capability development, exploitation of resources and participation in the international market. Although the literature of the impact of FDI is rather inconclusive, what seems to emerge is that there is a potential direct contribution to economic growth, whether through additions to the capital stock and/or technological base of countries. However, such potential contribution is dependent on the type of FDI involved and the absorptive capacity of the host country. For developing countries, FDI is an most important means of acquiring new technology, but it is evident that FDI is not a sine qua non for industrial and technological upgrading.

Cross-border M\&As can act as a tool for competitive upgrading (UNCTAD 2000). FDI through acquisitions can influence the rehabilitation of industrial activity, the injection of new technology and spillovers of knowledge into otherwise stagnant industries. It is argued that M\&As represent an important means how to restructure and upgrade industrial capabilities (Maucher 1998, UNCTAD 2000). This may happen in two ways. First by knowledge transfer to the acquired firm, and second, by the creation or upgrading of linkages with the domestic economy. The next section deals with each of these separately.

\section{Intra-firm knowledge transfer}

An acquired enterprise may benefit from technological upgrading, comprising both 'hard' (physical investment, plant and equipment) and 'soft' (knowledge, management systems, processes) technologies and may lead to rapid changes in the host country, particularly with respect to market orientation, local skills and capabilities, as well as corporate strategies to make the transition up the value chain. Upgrading in this way is 
confirmed by varied empirical evidence (see for example, Zhan and Ozawa 2000, Chudnovsky et al 1995, Mortimore 1998, Moden 1998). This upgrading includes the increasing capabilities of acquired firms because of the greater technological strengths that foreign investors potentially bring in as a result of the firm-specific assets of parent MNEs. This is also reflected in the knowledge flows from the acquirer to the acquired unit (Bresman et al 1999). Several studies show that FDI tends to raise output and/or productivity, through introduction of new technologies (e.g, Barrel and Pain 1997; Djankov and Hoekman 1999). Evidence also suggests that MNEs introduce new or improved management techniques to the acquired firms (Chudnovsky et al 1995, Allard and Lundborg 1998). Foreign affiliates are often at the forefront of new management and organizational techniques, quality management, standards, training and marketing methods, reflecting home country practices introduce new concepts to move the acquired firm towards the technological frontier.

However, it is important to note that acquired enterprises may not always experience a net technology inflow in a post-acquisition scenario. This depends inter alia upon the motive of the investment, and the role of the newly acquired subsidiary within the structure of the MNE. Once the decision to enter a given market through FDI is taken, the kinds of activity and the level of competence of the subsidiary are co-determined by the nature of the location advantages of the host location. That is to say, while MNE internal factors such as their internationalization strategy, the role of the new location in their global portfolio of subsidiaries, and the motivation of their investment are pivotal in the structure of their investment, all these issues are dependent on the available location-specific resources which can be used for that purpose. Indeed, the host country's location advantages play an important role in determining the level of embeddedness of the subsidiary (Benito et al 2003), and this is the primary determinant of the quality of the FDI. In some instances, MNEs may divest part of their operations because other subsidiaries in other countries within the MNE network are better positioned to perform these tasks. MNEs sometimes seek to rationalise their operations on a regional or global basis, and therefore reduce (or increase) the intensity of operations of an acquired subsidiary by lowering the level of competence and/or scope of their subsidiary (Narula 2003). Thus, whether an acquired firm is upgraded or downgraded upon becoming a part of an MNE is not always clear, since it is a function of not just the competences and resources that are available to the MNE, but also the MNE's global or regional strategy and how the newly-acquired subsidiary fits into its existing structure (Benito et al 2003).

If upgrading is analysed within the context of a categorization provided by Humphrey and Schmitz (2000), we look at process upgrading (firm processes- transforming inputs into 
outputs more efficiently by re-organising the production system or introducing superior technology), product upgrading (firms upgrading by moving into more sophisticated product lines - defined in terms of increased unit values), and functional upgrading (firms acquiring new functions in the value chain, broadening the scope of their industrial activity). While process upgrading refers to doing the same industrial activity more efficiently, product and functional upgrading refer to a repositioning by the industrial activity on to new, higher value added levels. In this paper, we take the approach that whereas each category of upgrading is equally important for the industrial and technological upgrading processes of the firm, it is best to analyse this with an interdependent dynamic perspective. Hence, an industrial restructuring process presupposes that there is process upgrading in the improvement of production processes towards more efficient and economically viable production. The basis for product upgrading, either brand development or repositioning, is determined by of process upgrading comprising investment in tangible and intangible technology. Improved production process also implies a strong element of functional upgrading in the enterprise.

The role of human capital is very important across forms of industrial upgrading. All forms of upgrading involve extensive reliance on the human capital. Upgrading results from both transfer of 'hard' and 'soft' technology and knowledge from the parent MNE to the affiliate through the application of firm-specific assets in the form of embodied and disembodied forms. Hard technology is said to include aspects of embodied knowledge, embodied in the machinery and equipment. Soft technology is said to include aspects of disembodied knowledge as a result of the transfer of operative skills and design.

\section{Technology Diffusion through backward linkages}

The perennial question posed in the literature on FDI and development is whether MNEs create linkages and become integrated in the host economy, or whether they operate in so-called 'enclave sectors'. When MNEs establish subsidiaries in a particular location they need to build linkages with domestic agents in order to carry out their operations, and these linkages constitute one of the ways in which skills and technological transfer is thought to disseminate to the rest of the economy.

The attention in various studies has been extensively laid upon the relationships between MNE affiliates and local suppliers, i.e. backward linkages of MNE affiliates in the

host economy. ${ }^{4}$ Various determinants of these backward linkages with local suppliers have been identified in the literature. There are factors related to the MNE and those associated with the host country. For example, the ability of the domestic economy to benefit from MNE 
investment crucially depends on the relative technological capabilities of the recipient and the transmitter. The presence of externalities per se does not imply that the domestic economy can or will internalize them, nor does it imply that these externalities have to be significant in quantity or quality. Ceteris paribus, MNEs prefer to use technologies that are suited to their own needs, and the purposes for which they have made the investment. MNEs generally do not make available their proprietary assets available at the whims of governments; rather they tailor their investment decisions to the existing market needs, and the relative quality of location advantages, especially skills and capabilities in which the domestic economy has a comparative advantage (Lall 2000) ${ }^{5}$.

Again, the MNE investment motive and its overall strategy are important factors to consider. For example, domestic market oriented affiliates generally purchase more locally than do export oriented firms because of lower quality requirements and technical specifications (Reuber et al 1973, Altenburg 2000). As a result, MNE affiliates are more likely to be integrated backward in the host country when they source relatively simple inputs (Ganiatsos 2000, Carillo 2001). For example, in the case of FDI in agro-based industries, there is a greater likelihood for affiliates to be integrated backward, especially given the early stage of development of the host country. Rodriguez-Clare (1996) argues that more linkages are created when MNE production uses intermediate goods intensively, when communication costs between parent and affiliate are large and when the home and host markets are not too different in terms of intermediate goods produced. Affiliates established through M\&As are likely to have stronger links with domestic suppliers than those established through greenfield investment (UNCTAD 2000, Scott-Kennel and Enderwick 2001) since such FDI can find established linkages upon acquisition that are likely to be retained if they are efficient ${ }^{6}$. Most importantly, linkages vary by industry. In the primary sector, the scope for location-specific vertical linkages is often limited, due to the continuous production processes and capital intensity of operations. In manufacturing, the potential for vertical linkages are broader, depending on the extent of intermediate inputs to total production and the type of production processes (Lall 1980). Blomstrom and Kokko (1997) suggest that 'some of the host country characteristics that may influence the extent of linkages - and thereby in the longer term the extent of spill-overs - are market size, local content regulations and the size and technological capability of local firms'. They argue that there is a propensity for linkages to increase over time, as the skill level of local entrepreneurs grows, new suppliers emerge and local content increases. The time factor is highlighted also by Rasiah (1994) and is related to the experience and integration of a MNE affiliate in the host country through greater 'indigenization' of 
operations in terms of management, knowledge about their location and operations ${ }^{7}$. The embeddedness of firms is often (but not always) a function of how long the MNEs have been present in the host country, since firms tend to build incrementally ${ }^{8}$.

Host countries need to have the basic endogenous absorptive capability structures (Abramovitz 1995) to be able to assimilate and take advantage of foreign technology made available in the host country. Knowledge accumulation is much more rapid once the initial threshold level of absorptive capacity exists (Criscuolo and Narula 2002). Technology diffusion through backward linkages presupposes that, first, domestic firms in the industry exist, and second, these possess the capacity to usefully internalise the knowledge being made available by the MNE. Diffusion to the rest of the economy may not occur because of deficiencies in the institutional capability systems of the host country or other deficiencies in the absorptive capacity of domestic economic agents in the host country. Learning and the acquisition of knowledge themselves require skills and abilities that are non-obvious.

\section{Research questions, propositions and methodology}

We reiterate our research hypotheses. Our first research focus relates to the analysis of the impact of FDI through technology transfer in acquired enterprises.

H1; FDI through acquisition leads to technology transfer within the firm, the intensity of which is determined by the absorptive capabilities and know-how present in the acquired firm.

The second research focus refers to the need to analyse the potential for MNE technology spillovers in the host country through evidence of vertical backward linkages of the acquired firms with other firms in the host country.

H2; FDI through acquisition leads to the establishment of more backward linkages and the nature of locally sourced inputs is determined by the technological capability of the linked firms.

The empirical evidence presented here is based on primary data collected from a study of FDI and MNE activity undertaken in Tanzania. This investigation was undertaken during 2002 and 2003 and comprised the use of exploratory questionnaire, as well as a comprehensive collection of data and related information on the FDI sector in Tanzania. 
Company visits and semi-structured interviews with management in a sample of foreign companies have been undertaken for this purpose ${ }^{9}$. This article focuses on two of the most important case of MNE affiliates in Tanzania whose acquisition took place in the early 1990s. On average, this time line permits us to have a seven-year period over which to examine their operations after acquisition.

Case study analysis was deemed the best method that could be used to provide an insight on the upgrading process within these MNE affiliates ${ }^{10}$. Studies of industrialization in Africa have not paid much attention to firm-level activities and industrial upgrading process which influence the path the various firms have followed and how they have been coping in changing world technological and market conditions (Wangwe 1997). We are fully cognizant that the case study approach has its limitations when it comes to making generalizations. Case studies are generalizable to theoretical propositions rather than to populations or universes. Unlike survey research, which relies on statistical generalization, our emphasis is more on the analytical generalization. We stop short of making generalizations from the case studies since these are made on the basis of cases which have been selectively sampled. The scope of this paper is more to gain an insight into the industrial upgrading process than in producing statistically significant outcomes ${ }^{11}$.

\section{Case studies and empirical evidence}

This section starts with a brief description of the two acquisitions studied and proceeds with an analysis of the empirical evidence in the context of the proposition posed earlier.

\subsection{Case studies}

\section{Tanzania Breweries Limited}

Tanzania Breweries Limited (TB) was privatised in 1993, after 16 years in state ownership, when it was bought by South African Breweries (SAB plc) in $1993^{12}$. TB is engaged in the manufacture, sales, distribution of beer, alcoholic fruit beverages (AFB's) and non-alcoholic beverages within Tanzania. The TB group is listed on the Dar es Salaam Stock Exchange, and has a market capitalisation of over US\$ 470 million, with over 22,000 Tanzanian shareholders. It employs more than 1,250 people and is represented throughout the country with three breweries in Dar es Salaam, Arusha and Mwanza, ten distribution depots, a traditional brewery and a distillery ${ }^{13}$. TB is also engaged in barley farming for use at its malting plant in Moshi. TB's mission is to be a successful brewer and profitable marketer of quality beers while being recognized as a good corporate citizen to stakeholders. The 
Company's vision is to be recognized as one of the most successful and respected commercial enterprises in East Africa by the year 2005 and aims to optimise the creation of wealth, and give a fair reward for the contribution of stakeholders. Their strategic objective is to grow shareholder value through enhancing volume and productivity growth, seeking opportunities to enhance its position on the local and export market, growing brands and achieve and maintain operational efficiency work hard to strengthen regional brands and market positions. Tanzania's beer market has potential for growth given its population size. However beer consumption levels are comparatively low when compared to neighbouring countries ${ }^{14}$. TB has a sales turnover of around US\$174 million (2003) of which around 5 per cent is exported to neighbouring countries. Key data for TB are shown in Table 1 below.

Table 1

\section{$\underline{\text { Tanzania Cigarette Company Limited }}$}

Tanzania Cigarette Company Limited (TCC) was formerly established in 1961 by the British American Tobacco. Its principal business is the manufacture, marketing and distribution of cigarettes. Between 1967 and 1975, the Government of Tanzania (GOT) completely nationalised the company. In 1995, as a result of Government's privatisation policy, 51 per cent of the company was sold to RJ Reynolds Tobacco Company, a subsidiary of RJR Nabisco, for US\$ 55 million. In May 1999, Japan Tobacco (JT) acquired all non-US tobacco operations of RJR Nabisco including its 51 per cent stake in TCC and in September 2000, JT increased its shareholding in TCC to 75 per cent. TCC became a public limited company in August 2000, with shares listed on the Dar Stock Exchange in November 2000. As a result, the shareholding structures stands at JTI 75 per cent, general public 19.5 per cent, GOT 5.5 per cent. TCC is currently the only cigarette manufacturer in Tanzania mainland and its sales turnover is around US\$ 100 million (2002), 10 to 15 per cent is exported to neighbouring countries within the parent network. TCC enjoys a local market share of over 95 per cent The company currently employs 700 people. TCC has a network of 680 wholesalers and 40,000 retailers. It has direct links with around 98,000 tobacco growers. Data pertaining to TCC are illustrated in Table 2.

Table 2

\subsection{Empirical evidence}


Next, we present case evidence pertaining to the analysis of our propositions. We do this in the following manner. First we highlight the main challenges for industrial upgrading emerging in the aftermath of the parastatal period. Afterwards, the process of technology transfer for restructuring taking into account the various forms of upgrading. Next, we examine the outcome of this restructuring process and evidence of vertical backward integration of these firms in order to highlight the potential for inter-firm technology spillovers in the host country. The underlying feature in this entire exercise is the emphasis on the nature and extent of absorptive capabilities within firms (both within the acquired firms and vertically linked firms) as a determinant factor for technology transfer in the former and technology spillovers in the latter.

Any examination of industrial upgrading and intra-firm technology transfer must be analyzed within the context of operative conditions in the parastatal period and hence the requirements for industrial restructuring emerging from such contexts. Both TB and TCC, were loss-making parastatals, depending extensively on public funds for operations, uncompetitive industrial activities with poor product quality and deteriorating market shares. This situation was the result of a number of structural deficiencies, mainly massive over employment, the utilization of obsolete technology, productive process with outdated work practices. For example, prior to 1993, TB's production facilities were characterized by old plant and equipment, archaic production methods which resulted in low capacity utilization, productive inefficiencies and deteriorating beer quality. The company was incurring continuous heavy losses in local market share (just over 40 per cent in the early 1990s) which served to exacerbate the precarious financial position ${ }^{15}$. A similar story can be told for TCC. While the company had a virtual monopoly of the protected domestic cigarette market, it was making substantial losses. TCC suffered from over-employment and weak technological and management capabilities and was losing market share to products from neighbouring countries, particularly Kenya. In general, the post privatisation experience is characterised by industrial and technological (including know-how) upgrading in different forms. This upgrading has occurred in all activities at TB (preparation, brewing, fermentation, packaging and sales) and TCC (processing, manufacturing, packaging and sales).

\subsection{Intra-firm technology transfer}

The immediate strategy post-privatisation at TB has been to undertake extensive 'physical' investment in plant and equipment with the objective to regain lost market shares through the modernization of production facilities, increase production capacity and improve 
efficiency and product quality. This process involved the rehabilitation of the main breweries in Dar es Salaam and Arusha, as well as setting up of a new brewery in Mwanza. This investment programme enabled TB to start utilizing state-of-the-art technology in its brewing process, i.e. more automated equipment particularly in the brewing and fermentation stages of the production process and bringing the company in line with technological standards envisaged by the parent MNE for best manufacturing methods in the industry. The rehabilitation of the Dar and Arusha plants has been done in a modular manner. Overall around US\$100 million had been spent in this modernization process and this capacity expansion programme has been completed in 2001, timed with the expiration of the company's tax holiday under Tanzania's fiscal incentives for FDI. Other modernisation has been undertaken in the packaging related machinery as for example, bottling and canning lines, labelling as well as in the upgrading of TB distribution facilities ${ }^{16}$.

As a result of this investment, TB has considerably improved its product efficiency, became more cost effective, improved the reliability of plant and machinery and reducing down time ${ }^{17}$. More automation has improved the production process, resulting in faster return on investment due to inceased production, reduced energy consumption and lower staffing levels ${ }^{18}$. Flexible production has resulted in the decrease of the turn down ratio to under 20 per cent of nominal capacity. Modern productive facilities have resulted in improved batch control that has improved product traceability ${ }^{19}$. The modernisation of the production process has also led to important improvements in the environmental impact of the breweries. For example, less energy consumption and liquid waste and increased recycling of waste from production are the most notable results in this respect ${ }^{20}$. Technology transfer has also taken place in subsidiary companies in the TB group. For example, at Tanzania Distilleries and Dar Brew, plant and machinery rehabilitation was undertaken within a restructuring programme aimed to increase capacity, productive efficiency, revamp traditional brands and undertake innovation in the product mix $^{21}$.

In addition to physical investment, 'soft' technology transfer has involved the application of parent MNE ownership advantages, particularly in the embodied in the production systems and methods. For example, quality checks from the raw material, input stage to the finished product stage have become more systemized, so as to determine the highest quality of beer produced as well as the determine the beer age in the trade (from more than 16 weeks to less than 12 weeks). Since acquisition, there has been a general emphasis on the improvement of the quality of beer produced. TB's sales and marketing departments have been overhauled, drawing on the extensive expertise of foreign personnel from the parent 
MNE. Greater focus has been put on brand research and development which has been dramatically improved in an effort to consolidate traditional beer brands whilst at the same time develop new ones. Foreign expertise has been brought in the company to effect changes in the production process and so that the functional departments meet the new strategic objectives of the company. The numbers of brands in the TB stable have increased from 2 in 1993 to 10 in $2003^{22}$. New product launches, such as '49er', a non-alcoholic beverage have been affected. 'Soft' technology transfer has occurred with respect to greater utilization of information technology when compared to the parastatal period. Prior to 1993, information and methods of its generation was not time-based, not seen as a priority for bringing about efficiency in business operations and limited to particular administrative tasks. Privatization necessitated the generation of more quality and timely information to be used by various firm stakeholders. Through the use of information technology, TB has in place a standardised control system for process units that can be configured to specific needs in the achievement of performance criteria. All this has enabled TB to achieve results in a relatively short time with return on investment increased rapidly after acquisition in 1993.

In the aftermath of privatisation, efforts were undertaken to arrest the under-utilisation of human capital. Training and human resource development was given utmost priority as a way to make the staff understand the new rules of a competitive business. Training was tailormade to suit the operations and included short-term courses in plant training seminars as well as overseas training ${ }^{23}$. In particular, a major in-house training programme was launched in 1994, with two main objectives to retrain production floor employees as well as to mould the more experienced, local capabilities into the MNE core competencies. Employment levels were decreased from over 4,000 in 1993 to 1,250 in 2003. This dramatic reduction is attributed to the technology changes (production is now computerised), outsourcing of services such as gardening, clearing, laundry, cargo loading, offloading and security, closure of certain distribution outlets and the upgrading of packaging lines which use two shifts not three. Forced retrenchment has been exercised and in other cases, jobs not requiring permanent employment have been identified and transferred into casual employment ${ }^{24}$. The number of expatriates amounts to just 5 per cent of total employment and reflects key managerial and technical posts. It is noteworthy that locals are well placed within the company managerial hierarchy. Expatriate personnel are required to pass on their knowledge to locals and total local staff complement is expected to be realised by 2007. Since acquisition, expatriates in management positions complemented local management to ensure that the new applied management systems and methods maximized the effectiveness of 
industrial restructuring being undertaken. Local capabilities are considered vital for the running of TB's operations since they involve extensive know-how of the industry (as a result of being employed in the company for many years) and intimate knowledge of market place. The new owners have recognized the importance of retaining these capabilities, as well as recruiting local talent in a bid to understand more the local culture, tastes and preferences. After acquisition, there has also been an overhaul in human resource development, through a re-organization and streamlining of operating structures to ensure cohesion and better coordination among various departments in line with respective roles vis-à-vis the company's core business $^{25}$. A strong element of disembodied technology has been to focus the human capital to best complement and optimise the new technology being utilized ${ }^{26}$.

SAB's competitive advantages in innovation processes and operative synergies have introduced new ways of working based on the undertaken of cross functional teams for shared decisions rather than through the isolated decision making process as was the norm prior to privatisation. As a result more delegation of power in decision-making at all operative levels has taken place:

“...an executive board under the executive managing director (comprising executive directors of the various operative departments meet regularly to make decisions and review company performance. They [the board] have been mandated by the board of directors to make decisions on its behalf since the directors board meets only four times a year to take major strategic policy decisions. Like this the delegation of powers has been pushed down the company hierarchy emphasising the importance of accountability" (TB company interview).

Therefore, outmoded management hierarchies were replaced resulting in better coordination and communication across the business section. This was facilitated by the concurrent specific training to selected employees in areas such as strategic quality management, cost control and operational efficiency. Important changes have been undertaken in the way the company measures employee performance to dispel the 'parastatal habit' of automatic salary increases with no relation to productivity ${ }^{27}$. TB now measures performance at the enterprise level rather than on individual basis and it sets annual productivity targets and bonuses are paid according to achievements. These changes have been aimed at instilling job responsibility and commitment ${ }^{28}$ and ensuring that production targets are met and new management practices effective. 
As a result of technology transfer, TB has therefore registered an overhaul in its productive activities, achieving a turn around in performance to the extent that production costs have been sufficiently reduced and permit a profit to be made on a reduced sale price of beer $^{29}$. TB performance since 1993 shows that there do exist opportunities for a profitable industrialized country brewing operation, even in developing countries (like Tanzania) where consumer purchasing power is relatively low, given that allowance is given to local conditions and through a gradual but intensive restructuring process. TB was transformed into a profit entity in just under two years: profit after tax amounted to US\$ 34.3 million in 2003. Accordingly, since 1993, the company has registered constant growth in operating margins, from 18.4 per cent in 1995 to 27.4 per cent in 2003. TB's operating margin stands above the best performing margin benchmark for the parent network of 26 per cent. At the basis of this performance lies the increase in sales turnover from an average of around US\$25.0 million prior to 1993 to over US\$130 million to date. The substantial plant and equipment investment led to an increase in production capacity from 0.4 million $\mathrm{hl}$ in the immediate aftermath of privatization to the current. 2.3 million hl. This increase was corresponded by an improvement in productivity indicators. For example, packaging efficiency and product quality standards by an average of 11 per cent, considerably cutting on waste and downtime $^{30}$. The number of productive man hours increased from 30 per cent (1993) to around 80 per cent (2002). Capacity indicators for TB's brewery landmark in Dar es Salaam (which produces 55 per cent of the national volumes) reflect an approximate capacity utilisation rate of 70 per cent up from below 50 per cent levels in the early 1990s. Productivity per employee increased by 6 per cent exceeding targets set by management of 3 per cent per annum. Concurrently, employee salaries registered a tenfold increase from the early 1990s. The financial soundness of the firm made it possible for the management to offer an attractive financial package to its workers an incentive for further for further enhancements of productivity. TB has also positively contributed to the government budget through taxes and dividends. Estimates indicate that TB's tax contribution increased from US\$ 12 million in 1993, to US\$ 63 million in 2002. Table 3 illustrates TB’s key performance indicators before and after privatisation in 1993.

Table 3

In the case of TCC, all nine operational departments ${ }^{31}$ have registered improvements in process, product and functional upgrading. Of primary importance to cigarette production 
is the activity undertaken in the leaf and manufacturing departments ${ }^{32}$ where substantial upgrading in operations, mainly in leaf procurement planning (cigarette component blending, processing, packing, qualification and purchasing), leaf logistics (including warehousing), and ongoing cigarette blend maintenance and related primary production issues have been registered. Furthermore, synergies have been established across functional departments, such as sales and marketing, product development and quality assurance departments to streamline the production process. Between 1995 and August 1998, TCC invested around US\$26 million in extensive factory renovation, commissioning of new plant and machinery and restructuring its primary processing, cigarette manufacturing and packaging activities. As a result, TCC's plant in Dar es Salaam has become more automated incorporating equipment that utilizes state-of-the-art technology such as 'programmable logic control' and 'mean weighted control' systems. For example, the adoption of the 'mean weight control' system which is an automated standard weight of tobacco in each cigarette stick has led to approximately US\$23 million in savings on raw tobacco.

In addition to the investment in 'hard' technology, the new owners implemented a number of process innovations in the various stages of the cigarette manufacturing process. For a start, the system to check the quality of sourced raw tobacco has been upgraded through more efficient plant layout and utilization of new machinery. As a result of the utilization of new automated equipment, substantial yield efficiencies in tobacco registered. The plant layout and the linkages between different operational departments has been streamlined to result in a leaner production process with, less slack, wastage and more productive efficiency. Since acquisition, the leaf and manufacturing department have been ISO 9002 certified and this has invariably led to improved product quality assurance. Cigarette production has to undergo rigorous quality control checks according to MNE parent quality standards before being sent to the packing machine stage. In addition, the company has been moving towards ISO 2000 certification, regarding health and safety and work environment standards. Investment in fixed assets particularly aims to maintain the equipment modern and up to international standards, maintain business continuity, loss prevention and safety.

The manufacturing process utilising modern and efficient machinery has led to substantial uniformity in product quality, improved cash flow efficiency and general product quality and consistency and less machinery down time. Invariably, the utilization of this technology has resulted in more uniform quality products, less wastage of raw materials, leading to substantial cost savings. Indeed, as a result of the investment in modern plant and equipment, productive efficiency has improved from less than 60 per cent in the early 1990s 
to over 85 per cent. Productivity measured by cigarettes produced per man-hour has increased from around 3,300 in 1997 to around 8,400 in 2000. Machine downtime has been reduced by more than 80 per cent since 1997. TCC has increased its production capacity from 1.5 to 5 billion cigarette sticks. Currently, the department manufactures 3.3 billion cigarettes annually amounting to less than 70 per cent capacity utilisation. Operational efficiency has increased from 70 per cent to 85 per cent. For example, 1 shift used to have 100 persons on board now has only 54 people, 2 shifts are operated in the production floor. Cigarettes are produced more efficiently as a result of new industrial machines capable of producing 8000 cigarettes per man hour. Leaner production methods have led to cuts in manufacturing costs. Modern equipment has increased yields from both leaf and NTMs (non tobacco materials). Investments in manufacturing technology and processes, quality assurance, new products, brand equity, distribution network and computerization are expected to continue to strengthen competitiveness and increase efficiencies.

In the emerging context of technology transfer from the parent MNE, TCC has thus been able to improved product quality and strengthen and reposition its brand portfolio. There has also been a refocusing of export business in markets with significant long-term growth opportunities. TCC can now produce to an international quality standard and has a cigarette portfolio of 11 brands directed at various consumer segments ${ }^{33}$. In November 1996, Aspen became the first international JTI brand to be produced by TCC and has since been successfully exported to neighbouring countries. TCC launched Winston and Winston Lights, in 1998 and 1999, respectively, the Winston brand being one of JT's flagship brands ${ }^{34}$. Upgraded technological capabilities has thus permitted TCC to undertake the production of both Virginia and American blend cigarettes to international standards. Sportsman and Sweet Menthol brands remain the biggest selling brands accounting for over 70 per cent of total sales volume. In September 2002, TCC introduced Embassy Kings. The company invested over US\$ 2 million in 2002 in sales and promotion to support and to strengthen brand equity. In the context of the 10 to 20 per expanding its export orientation, TCC has acquired the total share capital of RJR Kenya Limited and renamed it as TCC (Kenya) limited.

Yield efficiency stands at a 98 per cent. Through 'mean weigh control' technological systems the exact weight of tobacco in the cigarette stick is implemented and the variation between one stick is now at most $20 \mathrm{mg}$, ensuring savings to the tune of \$20 to 23 million. This has raised production from less than 3,000 sticks per minute to 8,000 sticks per minute. By the fiscal year ending December 2001, TCC's turnover had increased by 85 per cent to reach US\$ 88.5 million from US\$ 47.9 million in 1985. Total tax contribution (VAT and 
excise) to the Treasury reached a record high of US\$ 40 million In 2001. TCC’s exports both regionally and internationally have been steadily increasing and represented about 10 per cent of sales volume in 2001. TCC is the largest agro-based industry in Tanzania adding substantial value to one of the country's main commodities. Key performance indicators of TCC are equivalent to those in JTI subsidiaries in Europe and the Middle East. The progress achieved in terms of cost and productive efficiencies has enabled TCC to prepare the groundwork for the implementation of JTI recently launched global enterprises resource planning initiative (ERP) initiative. TCC has been undertaking this exercise since 2003 and runs until 2004. In the same vein, TCC is implementing the 'Rhino' project running from the second half of 2002 until 2006, aiming at continuously improving the company's product quality and achieve costs efficiencies through reorganization of the factory layout, optimisation of the headcount and employee development. Key performance indicators for TCC in the aftermath of privatisation are illustrated in Table 4.

Table 4

As in the case of TB, the human capital component was vital in the achieving various forms of upgrading and benefiting from the forms of technology transfer from the parent company. In the immediate aftermath of privatisation, staff complement downsizing was undertaken $^{35}$. The workforce was reduced from 1300 (750 on the production floor) to 730 (300) over four years. The main downsizing was undertaken in the production floor, as a result of extensive automation of plant and equipment which led to a drastic decrease in manual jobs. There are only 3 expatriates in the company who are employed in key executive and technical roles. Locals are employed in key management positions (such as technical, administrative and sales and marketing positions) as a result of the extensive capabilities and host country experience they possess.

TCC gives considerable importance to human resource training and development. It has put in place extensive internal and external training programmes. TCC is one of the main employers in the host country, and seeks and retains the best young graduates in Tanzania, providing them with career advancement opportunities as well as external training and secondments to other JTI plants around the world. TCC set up an on-site training centre late 1997 to spearhead this strategy. The initial post-privatisation training mainly focused on generic training to enhance employee awareness of organisational change, professionalism and life skills. Substantial changes to the work ethic inherited from parastatal period was 
required. The continuing training initiatives addressed employees' individual development needs and increase effectiveness, particularly of those employees at the production floor without basic skills but who were deemed to be trainable. Other training programmes have been aimed at broadening managers' international exposure within the parent network and the MNE training centre in St. Petersburg, Russia. For example, a system of secondment of TCC personnel to sister affiliates has picked momentum in recent years and a number of local personnel from middle management upwards have already benefited. These training programmes are emphasised for the development of senior management, i.e. supervisory and technical staff. A threshold level of capability for production floor workers was important as the company has been modernising its plant and equipment. For example, suppliers provide training on specific machinery prior to commissioning so that when the actual machinery is installed in the Dar es Salaam plant, it can be utilised immediately without undue work stoppages. Normally, employees short term ad-hoc training courses with direct relevance to on-the-job specific tasks.

As a result of the considerable staff training and the introduction of new management methods, extensive manpower efficiency has been achieved. The upgrading process is expected to continue in the future, as future human resource objectives will focus on organisational development through management development and job-specific training. Within line management, strategies currently in the pipeline include the development of areas of management in accordance to the 'frontier' parent standards to ensure a talented pool of candidates ready for progression within the company and further 'indigenize' the affiliate. A noteworthy change in the human resources has been the re-focusing of individual contribution to corporate goals. Parastatal working practices have been changed and every stage in the production process has become systemized according to ISO 9002 certified specifications. In contrast to the parastatal period, every task in the company is now defined, with detailed job description and performance is evaluated accordingly ${ }^{36}$. A global suggestion system for empowering shop floor workers to contribute to and take ownership for operational improvements was implemented in 2002. A significant number of high quality suggestions were received from personnel and resulted in improved processes and cost savings. It is noteworthy that a number of production floor suggestions have been also diffused throughout the parent network and adopted as best practice.

The utilisation of information technology has also been an important change. For example, TCC receives all the information from its branches scattered all over the Tanzania mainland within two days at most and this information is processed for submission to the 
management who in turn transmit it to the parent company head office in Geneva. ${ }^{37}$ Systems that generate timely data and information have also been implemented with considerable success at TB.

Hence, prior experience in the business or industry is regarded as an important in providing present owners with knowledge of current operations. Without the support of previous managerial experience for innovation, it was difficult to develop a successful innovation programme. The experience and exposure of the managers at TB and TCC are shown to have been a dynamic source of innovation, high productivity and competitiveness.

\section{MNE vertical backward linkages}

Next we analyse the vertical backward integration of the cases being studied. We recall our earlier proposition that seeks to highlight the potential for inter-firm technology spillovers in the host country as a result of backward linkages established by the newly acquired firms. As highlighted earlier on, our premise here is that vertical backward linkages of the acquired firms with host-based firms serves as a medium for MNE technology spillovers in the host country. We draw attention to three main aspects. First of all there is a need to ascertain whether MNE affiliates have established vertical backward linkages in Tanzania. Second, there is need to analyse whether, as the literature suggests, local sourcing has increased as a result of the MNE acquisitions. Finally it is important to analyse the technological characteristics of local sourced inputs, as this should shed light on the technological capabilities of the linked firm. In this context, we distinguish between resource based inputs, low and medium technological intensive manufactured inputs.

Following acquisition by SAB, TB initiated a comprehensive programme of local sourcing. Local sourcing makes also strong economic and logistical sense for the company. In the immediate aftermath of privatisation almost all inputs to the production process were imported from within the parent network. However, this started to change as a result of a number of factors, notably the new strategic objectives of safeguarding profits by reducing costs (greater cost control can be exerted on locally procured inputs) and improving the corporate citizen image of the firm in the host country by generating and visibly benefiting the host economy through linkages. In addition, there are important logistical considerations for local sourcing. There is a six week lead time from SAB's plc main parent sourcing hub in Durban, South Africa, to Dar es Salaam, for imports of key production inputs and any stoppages occurring at source can therefore cause stoppages in TB's production plants in Tanzania. Hence proximity to suppliers is deemed also important in terms of logistical and 
business continuation. In the context of this strategic development therefore, TB identified a number of inputs to the production of beer that could be sourced locally from the primary inputs (barley) to other intermediate inputs in the packaging process. For example, currently, TB sources approximately 30 per cent of its barley requirement from domestic sources. For this purpose, TB has set up a maltings plant in Moshi to systemize the purchase of barley from over 500 farmers in the region. In 2000, approximately US\$ 2.4 million were paid to farmers for the crop, representing the single largest source of direct income for farmers in the region. In the near future, TB plans to meet the entire barley requirement from local sources (increasing from 6,000 to 26,000 tonnes) through further investment in research and development of the crop to improve yields and deepening of the present linkages with the farming community. Another important backward linkages established by TB is the sourcing of locally manufactured glass beer bottles. The supplier, KIOO Glass Ltd, an MNE affiliate, has established close technical collaboration with TB so as to meet production quality requirements ${ }^{38}$. Another supplier in Tanzania for TB is Carnaud Metal Box, manufacturer of metal crown corks. This supplier is also a long established foreign affiliate and was the first supplier to enter into a technical collaboration with TB after privatisation in 1993. In addition, TB sources plastic crates and shrink-to-fit packaging from Simba Plastics and is currently sourcing some of its bottle label requirements from Tanzania Printers, a local printing company (labels). TB has also established strong backward links with Showerlux Ltd, manufacturer of industrial chemicals. Around 36 per cent of TB's inputs are sourced locally and plans are underway to increase this percentage to 50 per cent in the next 3 to 5 years.

TCC industrial restructuring since 1995 has catalysed investment in upstream industrial activities particularly the farmers and growers who supply the raw tobacco. During the 1996-2000 period, the revitalization of TCC has also served to 'crowd in' other foreign investment in Tanzania in tobacco processing activities. Indeed, around US\$ 65 million was invested in the sector by leading world tobacco merchant MNEs ${ }^{39}$. Two of the largest tobacco leaf processors and sellers in the world, Universal and Dimon, have invested over US\$60 million in new factories in Tanzania, following the restructuring of TCC. Total tobacco processing plants have a combined processing capacity of 78 million $\mathrm{kg}$. per annum and these operations are vertically linked with TCC. These tobacco processors source raw tobacco from farmers, process the raw material which then they sell to TCC for the manufacturing of cigarettes $^{40}$. On the one hand, there is TCC's ongoing investment and requirements for quality tobacco, as well as the 'crowding in’ of this investment in tobacco processing. Annually, TCC buys approximately around 1,800 tonnes of raw tobacco for the purpose of manufacturing 
cigarettes and 2,000 tonnes for the purpose of exports to other plants within the parent network. This backward linkage makes TCC one of the leading agro-based local value added manufacturers in Tanzania. In addition to the raw tobacco, TCC has also established noteworthy vertical ties with printing packaging suppliers.

Both TB and TCC are the main active partners in the so called, Tanzanian Private Sector Initiative (PSI). PSI has been established to develop and expand the role of the corporate private sector in Tanzania in a bid to increase the opportunities for small local business to contribute to, and participate in the pro-poor growth of the Tanzanian economy, i.e. to promote more linkages as part of successful business operations. In other words, the PSI has been intended as a vehicle for large companies (mainly foreign affiliates in Tanzania) to work collectively in partnership with each other, donor agencies and government. It thus serves as a catalyst to cause greater involvement of the private sector engaged in local enterprise development and social investment towards effecting sustainable development and poverty reduction ${ }^{41}$. Since privatisation, both companies have been at the forefront of vertical integration in the host country, by increasing the nature and extent of backward linkages with host-based firms.

On the basis of the above evidence, three main points regarding linkages emerge., i.e. the evidence of vertical backward linkages, the hypothesised positive impact of the acquisition on establishing new linkages and technological characteristics of sourced inputs. It is clear that in both cases, backward linkages in the host country have been established and there is evidence that there is a potential for technology spillovers to emerge between the affiliates and their suppliers ${ }^{42}$. FDI through acquisitions has resulted in more backward linkages being established when compared to the situation in the pre-acquisition period. The deepening of local value chains has primarily been the result of the affiliates' growth and turnaround in productive performance. Whereas in the formerly stagnant, under capitalized and almost declining industries, the scale and scope for vertical linkages was almost nonexistent, this is not the case following privatisation. Nevertheless, it is the prerogative of new foreign owners to decide whether to source locally or from abroad, for example through the parent network. Production volumes have increased, new products and brands developed and this has led to an increased input requirements to respective production processes of beer and cigarettes. TB has increased or in almost all cases, started backward linkages with locally based firms. This has been the result of a comprehensive effort by the affiliate to 'look around for and develop technical collaborative agreements with locally based suppliers' (Company interview, 2002). In the parastatal period, local sourcing was not the norm and enterprises 
preferred to import intermediate inputs from neighbouring countries. Cost, competitive and logistical considerations were not considered important at that time. Following the liberalisation of the economy and the restructuring of $\mathrm{TB}$, cost and logistical factors assumed greater importance in the pursuance of the company's strategic objectives. Hence, as a procurement strategy, local sourcing was deemed as 'making a lot of sense' (Company interview 2002). This is also the case with TCC. In the pre-liberalisation period, production volumes were abysmally low and this had a negative impact on the tobacco cultivation and processing industry. After liberalisation and TCC's restructuring programme, the tobacco industry picked up, reinforcing the local value chain.

From the evidence of vertical backward linkages, it emerges that MNE affiliates source different inputs (with different technological characteristics and/or intensity) from different firms simultaneously. This information is important since it sheds light on the potential technology spillover effects from the MNE to its local suppliers. It is widely accepted that sourced intermediate inputs reflect different technological characteristics in terms of the nature and extent of production process involved in their production, the physical and human capital involved in their production as well as the material which they are produced. Through the overview of the MNE affiliates locally sourced inputs, we can distinguish between resource-based, low and medium technology inputs. For TB and TCC, the 'lion's share' of inputs reflect primary, resource-based inputs. Since acquisition, both TB and TCC have developed vertical backward linkages with local farmers in the barley and tobacco sectors, respectively ${ }^{43}$. Indeed, these linkages reflect the 'match' existing between local economic activities; i.e. those found in agriculture and the agro-food manufacturing industry in which the two MNE affiliates operate ${ }^{44}$.

\section{Conclusions and implications}

Using a case-study approach, this study examines the role of privatisation on the industrial landscape of Tanzania in the agro-foods sector. The main findings suggest that on the whole technological upgrading has occurred following the acquisition by MNEs. We analysed the potential of technology diffusion through backward linkages and concluded that there is evidence of improved backward linkages with local economic actors. Capabilities in the host country context, both within the acquired firms and also in the supplier base of the host country, matter for the magnitude and intensity of technological upgrading. It is worth emphasising that both of the cases were in an industrial sector which match the comparative advantage of the host country. Domestic capabilities in other, more technology-intensive 
sectors would be considerably lower, and it would unreasonable to expect such positive results. It is therefore important to emphasise that our results should only be generalised with great caution. 'Wider' technology gaps between the domestic and foreign-owned sector are more likely to result in fewer backward linkages as well as the type of technological content of inputs sourced locally.

It is important to highlight some caveats that emerge from the analysis which may be relevant to the discussion of upgrading. The sustainability of the acquired firm's operations given the multitude of constraints in the local market is another factor worth considering when assessing the implications of vertical linkages. It is true that greater integration of foreign affiliates is a positive implication for the host country through the potential spread of technological spillovers and demonstration effects of acquired firms to their suppliers and customers. The relevance of this issue is exacerbated by the dearth of an indigenous industrial base generating economic activity.

There are also a number of caveats regarding MNE backward linkages in the host country. However, while vertical linkages with other foreign affiliates based in the host country may be important, these linkages may not offer the same type of potential for externalities in the host countries. Here, the issue revolves around the presence of a competitive and capable domestic industrial base able to link up with MNE affiliates. In the cases examined, it is evident that in the case of backward linkages reflect primary activities in the case of local suppliers and more manufactured inputs with various types of technological capabilities in the case of foreign suppliers. This represents a notable variation to consider when promoting policies for the 'indigenization' of FDI and MNE activity. Although the formation of backward linkages is a noteworthy, positive development, the size and market power of foreign affiliates in the host country can affect negatively local suppliers as highlighted in Altenburg (2000) and Brimble (2001) ${ }^{45}$. In the absence of a realistic counterfactual, one can argue that the MNE vertical linkages established with the present suppliers are leading to externalities that would have otherwise not existed. Probably in the short and medium term it is 'easier' for government to promote further an enabling investment climate so that these FDI activities are consolidated further, because in the present circumstances these vertical linkages (foreign to foreign) represent the sole available mode of industrial upgrading and capability development in Tanzania being diffused to other host based economic activity. As long as industrial and technological upgrading happens and spills over to more than one firm, it does not matter who the beneficiary is if it serves to embed further the MNE affiliate in the host country. However, this outcome should not be taken as 
an end in itself but a means to an end. Further research is needed to gather more insights on the technology transfer aspects of FDI through acquisitions, as well as regards the technological and knowledge spillovers of MNE affiliates to their local suppliers. 


\section{References}

Abramovitz, M. (1995), 'The Elements of Social Capability’, in Perkins, D.H. and Koo, B (eds.), Social Capability and Long-term Growth, Basingstoke: Macmillan Press.

Allard, P. and Lundborg, L. (1998), 'Foreign acquisitions of Swedish companies: a study of internal and external effects’, ISA Studies on Foreign Direct Investment, No.5 (Stockholm: Invest in Sweden Agency).

Altenburg, T. (2000), 'Linkages and Spillovers between Transnational Corporations and Small and Medium-sized Enterprises in Developing Countries: Opportunities and Best Policies', in UNCTAD, TNC-SME Linkages for Development: Issues-Experiences-Best Practices. New York and Geneva: United Nations.

Barrel, R. and Pain, N. (1997), 'Foreign Direct Investment, Technological Change and Economic Growth Within Europe’, Economic Journal, v.107 (445).

Belderbos, R., Campanelli, G. and Fukao K., (2001), 'Backward vertical linkages of foreign manufacturing affiliates: Evidence from Japanese multinationals', World Development, 29, 1, (189-208).

Benito, G., Grogaard B., and Narula, R. (2003), 'Environmental influences on MNE subsidiary roles: Economic integration and the Nordic countries’, Journal of International Business Studies, 34, (443-456).

Blomstrom, M. and Kokko, A. (1997), 'How Foreign Investment Affects Host Countries', Policy Research Working Paper, The World Bank.

Bresman, H., Birkinshaw J., and Nobel R. (1999), 'Knowledge Transfer in international acquisitions', Journal of International Business Studies, 30, 3 (439-462).

Brimble, P. (2001), 'The Thai Hard Disk Drive Industry’, UNCTAD (Geneva: UNCTAD), mimeo.

Carillo, J. (2001), 'Foreign direct investment and local linkages: experiences and the role of policies. The case of the Mexican television industry in Tijuna', UNCTAD (Geneva: UNCTAD), mimeo.

Castellani, D and Zanfei, A. (1998), 'Multinational growth and the creation of linkages with local firms: evidence from the electronics industry”, paper presented at the IRD\&P workshop on the Economics of Science and Technology: Micro-Foundations and Policy (Italy, University of Urbino), 5-6 June.

Chudnovsky D., Lopez, A. and Porta, F. (1995), 'New foreign direct investment in Argentina: privatization, the domestic market and regional integration', in Manual R. Agosin, ed., Foreign Direct Investment in Latin America (Washington, D.C.:Inter-American Development Bank), (39-104). 
Criscuolo, P and Narula, R. (2002), 'A Novel Approach to National Technological Accumulation and Absorptive Capacity: Aggregating Cohen and Levinthal', MERIT Research Memorandum, 2002 - 16.

De Mello, L.R., Jr. (1997), 'Foreign direct investment in developing countries and growth: A Selective Survey’, Journal of Development Studies, Vol. 34, (1-34).

Djankov, S and Hoekman, B. (1999), 'Foreign Investment and Productivity Growth in Czech Enterprises’, World Bank Economic Review, Vol. 14, (49-64).

Driffield, N and Mohd Noor, A. (1999), 'Foreign direct investment and local input linkages in Malaysia’, Transnational Corporations, 8 , 3 (1-24).

Findlay, R. (1978), 'Relative backwardness, direct foreign investment and the transfer of technology, a simple dynamic model’, Quarterly Journal of Economics, Vol, 92, (1-16).

Ganiatsos, T. (2000), 'Global component outsourcing in developing countries' electronics and automotive industries', paper submitted to the UNCTAD Expert Meeting on the Relationship between SMEs and TNCs to ensure the competitiveness of SMEs (Geneva), 27-29 November, mimeo.

Gorg, H and Ruane F. (1998), 'Linkages between multinationals and indigenous firms: evidence fro the electronics sector in Ireland’, Trinity Economic Papers, Technical Paper 13 (Dublin: Trinity College).

Government of Tanzania (1999), The Tanzania Development Vision, 2025, Planning Commission, The United Republic of Tanzania, Dar es Salaam.

Humphrey, J and Schmitz, H. (2000), 'Governance and upgrading: linking industrial cluster and global value chain research, IDS Working Paper 120, Brighton, Institute of Development Studies.

Jo, S. H. (1980), 'Direct foreign private investment', in Chong Kee Park, ed., Macroeconomic and Industrial Development in Korea (Seoul: Korea Development Institute), (129-182).

Kumar, N. (1990), ‘Multinational Enterprises in India, (London: Routledge).

Lall, S. (2002), 'Implications of Cross-Border Mergers and Acquisitions by TNCs in Developing Countries. A Beginner’s Guide’, QEH Working Paper Series, No. 88, June.

Lall, S. (2000), 'Transnational Corporations and Technology Flows', in D Nayyar (ed), New Roles and Functions for the United Nations and Bretton Woods Institutions, Helsinki; UN University WIDER.

Lall, S. (1980), 'Vertical Inter-firm Linkages in LDCs: An Empirical Study', Oxford Bulletin of Economics and Statistics (August 1980) (209-222).

Landi, J, (1986), 'The sourcing policies of MNEs: a case study of Nigeria, (University of Reading), PhD thesis. 
Liberatori, M and Pigato M. (2000), 'FDI Through Privatisation in sub-Saharan Africa', World Bank, Washington, D.C.

Lim, L and Pang, E.F. (1982), 'Vertical Linkages and Multinational Enterprises in Developing Countries’, World Development, Vol. 10 No.7 (585-595).

Maucher, H.O. (1998), 'View: Mergers and Acquisitions as a means of restructuring and repositioning in the global market - business, macroeconomic and political aspects', Transnational Corporations, 783), (153-83).

Mbelle, A and Shitundu J, (1999), 'The Management of Industrial Reforms in Tanzania. Perspectives and New Challenges’, mimeo, Economics Department. ERB, Dar es Salaam.

McAleese, D and McDonald, D. (1978), 'Employment growth and the development of linkages in foreign-owned and domestic manufacturing enterprises', Oxford Bulletin of Economics and Statistics, November, (321-339).

Moden, K. M. (1998). 'Foreign acquisitions of Swedish companies: effects on R\&D and productivity' (Stockholm: Research Institute of Industrial Economics), mimeo.

Mortimore, M. (1998), 'Getting a lift: modernizing industry by way of Latin American integration schemes. The examples of automobiles', Transnational Corporations, 7, 2 (August), (97-136).

Mwandenga, A. (2000), 'Socio-economic impact of privatization: The Tanzania Experience', African Journal of Finance and Management, Vol, 19, No. 1, July 2000.

Narula, R. (2003), 'Switching from import substitution to the 'New Economic Model' in Latin America. A case of not learning from Asia', MERIT Research Memorandum Series, 2002-032.

Narula, R. and Dunning, R. (2000), 'Industrial Development, Globalisation and Multinational Enterprises: New Realities for Developing Countries’, Oxford Development Studies 28(2) (141-167).

Noorbaksh, F, Paloni, A and Youssef, A. (2001), 'Human Capital and FDI Inflows to Developing Countries: New Empirical Evidence’, World Development, Vol. 29, No. 9, (1531610).

Pigato M. (2001), 'The foreign direct investment environment in Africa'. Africa region working paper series No.15. World Bank, Washington DC.

Rasiah, R. (1994), 'Flexible production systems and local machine tool subcontracting: electronics component multinationals in Malaysia', Cambridge Journal of Economics Vol. 18: (279-98).

Reuber, G.L., Crookell, H., Emerson, M. and Gallais-Hamonno, G. (1973), 'Private Foreign Investment in Development', (Oxford: Clarendon Press). 
Rodriguez-Clare, A. (1996), 'Multinationals, linkages, and economic development', American Economic Review 85, (852-73).

Scott-Kennel, J and Enderwick, P. (2001), 'The degree of linkage of foreign direct investment in New Zealand industry’. (Wellington: Victoria University of Wellington), mimeo.

UNCTAD, (2001), World Investment Report 2001: Promoting Linkages. New York and Geneva: United Nations.

UNCTAD, (2000). World Investment Report 2000: Cross-border mergers and acquisitions and development. New York and Geneva: United Nations.

Wangwe, S. (1997). 'Economic Reforms and Poverty Alleviation in Tanzania', Discussion Paper No. 16, Economic and Social Research Foundation, Dar es Salaam.

Yin, R.K (1984). Case study research: design and methods. Beverly Hills, CA: Sage Publications.

Zhan, X. J and Ozawa, T. (2000), 'Business Restructuring in Asia: Cross-border M\&As in Crisis affected Countries’ Copenhagen Business School Press. 
TABLE ONE

Tanzania Breweries Limited - Basic indicators

\begin{tabular}{|c|c|c|c|c|}
\hline & 1994 & 1997 & 2002 & 2003 \\
\hline Turnover (in US million) & 29.0 & 119.2 & 135.0 & 174.0 \\
\hline Profit before tax (in US million) & -1.0 & 19.0 & 34.3 & 47.6 \\
\hline Cash flow from operations (in US million) & 0.6 & 17.2 & 30.1 & 43.2 \\
\hline Net cash invested to expand operations (in US million) & 6.0 & 10.5 & 3.3 & 1.1 \\
\hline Total number of employees & 3,000 & & & 1,250 \\
\hline Number of persons receiving training in Tanzania & - & 746 & 1,201 & 1,089 \\
\hline Number of persons receiving training abroad & - & 23 & 31 & 31 \\
\hline (in 000 US dollars) & 1997 & 2000 & 2002 & 2003 \\
\hline Cash derived from sales & 119.200 & 169.900 & 166.300 & 208.300 \\
\hline Cash paid to suppliers & 47.400 & 63.100 & 57.000 & 64.900 \\
\hline Cash value added & 72.200 & 107.100 & 109.300 & 143.500 \\
\hline \multicolumn{5}{|l|}{ Cash utilised to } \\
\hline Remunerate employees for their services & 9.100 & 13.200 & 9.900 & 10.800 \\
\hline Pay direct taxes to Government & 600 & 600 & 7.200 & 11.200 \\
\hline Pay excise duty and Value Added Tax & 44.000 & 62.500 & 62.200 & 77.800 \\
\hline Cash disbursed among stakeholders & 65.500 & 100.800 & 103.300 & 142.400 \\
\hline Cash retained for re-investment ${ }^{a}$ & 6.700 & 6.300 & 6.000 & 1.1000 \\
\hline
\end{tabular}

Source: Field Interviews and Company Annual Reports 


\section{TABLE TWO}

Tanzania Cigarette Company Limited - Basic Indicators

\begin{tabular}{lrrr} 
& $\mathbf{1 9 9 6}$ & $\mathbf{1 9 9 9}$ & $\mathbf{2 0 0 1}$ \\
\hline & & & \\
Sales turnover (in US million) & 61.7 & 77.6 & 88.5 \\
Profits before tax (in US million) & 7.7 & 15.3 & 21.6 \\
Profits after tax (in US million) & 5 & 15.3 & 22 \\
& & & \\
Cigarettes manufactured per man hour & 3,000 & 6,000 & 8,400 \\
Machine efficiency (percentage) & 51 & 76 & 78 \\
& & & \\
Total number of employees & 1,205 & 730 & 735 \\
\multicolumn{1}{c}{ Sales } & 269 & 279 & 286 \\
Administration & 232 & 192 & 194 \\
Manufacturing & 704 & 259 & 255 \\
\end{tabular}

Source: Field Interviews and Company Annual Reports

TABLE THREE

Performance indicators for Tanzania Breweries Limited

Pre - privatization Post-privatization

Sales turnover (in US\$ million)

Production level (in hecto litres)

Capacity utilisation (in per cent)

Number of product brands

Local market share (in per cent)

Exports (in per cent)

Number of employees

Profit before tax (in US\$ million)

Indirect taxation to government (in US\$ million)

Dividend (declared/proposed) (in US\$ million)
29.0

0.4 million

25

2

31

1.5

3,050

$-1.0$

32.0

8.8
135.0

2.3 million

80

10

85

5.0

1,250

34.3

77.8

30.8

Source: Compiled by authors from field Interviews and company annual reports 
TABLE FOUR

Performance indicators for Tanzania Cigarette Company Limited

Gross turnover (in US\$ million)

Profit before tax (in US\$ million)

Number of employees

Number of product brands

Production capacity (in sticks)

Capacity Utilisation (in per cent)

Local market share (in per cent)

Excise \& VAT (in US\$ million)

Dividend paid (in US\$ million)
61.2

7.7

1,500

3

1.5 billion

51.0

60.0

35.0

4.0
88.5

21.5

730

8

5 billion

80.0

95.0

39.4

22.7

Source: Compiled by authors from field Interviews and company annual reports 


\section{NOTES}

${ }^{1}$ For the examination of MNE affiliate vertical linkages, we use the definition of Lall (1980), who defines linkages as being the 'direct relationships established by firms in complementary activities which are external to 'pure' market transactions' and 'essential to the functioning of any normal industrial market and transactions that go beyond arm's length, one-off relations and involve longer-term relations between firms' (p. 204). The relationship over time involve sustained exchanges of information, technology, skills and other ownership assets.

2 See for example the strategy document “Tanzania Development Vision, 2025” (GOT 1999). Tanzania's economic policy two decades ago involved the outright barring of FDI. The present attitude towards FDI represents a dramatic turnaround in policy. The privatisation of parastatal companies started in the early 1990s with a total of 257 companies being divested.

${ }^{3}$ These figures also include portfolio investment. Portfolio investment substantially declined in the aftermath of the Asian crisis to less than 10 per cent of total foreign exchange.

${ }^{4}$ In a study on Nigeria, foreign affiliates had a higher propensity to import than their local counterparts (Landi 1986). Similar conclusions have been made in the cases of Ireland, Republic of Korea and India (McAleese and McDonald 1978, Jo 1980, Kumar 1990).

${ }^{5}$ The literature on spillovers tends to ignore another important factor: that not all MNE subsidiaries will provide spillovers and linkages to the same extent.

${ }^{6}$ In the case of Japanese MNEs, Belderbos et al (2001) conclude that acquired affiliates had significantly higher local content levels than those established through green field investment due to their pre acquisition integration in the local economy.

${ }^{7}$ See for example, Driffield and Mohd Noor 1999, Castellani and Zanfei 1998, Gorg and Ruane, 1998.

${ }^{8}$ This has been observed to be the case in East Asia (See e.g., Rasiah 1994), but it is to be noted that firms build on location advantages that already exist in the host economy and increases in embeddedness are generally in response to improvements in the domestic technological and absorptive capacity.

${ }^{9}$ Questionnaire data was based on three main aspects; information on the affiliate and ownership structure, the FDI motive and established vertical linkages of the affiliate in the host country. Emphasis was put on the main changes that have taken place within the firm as a result of privatisation. Multiple visits in certain cases where undertaken to verify and clarify information sought in the first instance. Interviews were held with company managers and every effort has been made to interview personnel who could provide an overview of pre and post privatisation stances. Precautions have been taken to reduce the risks entailed in the case study approach. Taking advantage of suitability of the case study approach to handle a variety of evidence, the information obtained in interviews has been complemented by information from official and unofficial documents and by follow-up interviews to obtain the necessary clarifications.

${ }^{10}$ The case study approach can be applied to at least three different situations in evaluation research: to explain the causal links in real-life interventions that are too complex for other research strategies, to describe the reallife context in which an intervention has occurred or for illustrative purposes, and to explore those situations where a single set of outcomes is not clear. Case studies are the preferred approach when 'how' and 'why' questions are posed, when the investigator has very little control over events and when the focus is on a contemporary phenomenon within its real-life context (Yin 1984).

${ }^{11}$ Precautions have been taken to reduce the risks entailed in the case study approach. To take advantage of the unique ability of the case study approach to handle a variety of evidence, the information obtained in interviews has been complemented by information from official and unofficial documents and by follow-up interviews to obtain the necessary clarifications. In the case of Africa, the extent of industrial development and type of FDI activity may suggest that technology absorption and diffusion through backward linkages might occur in outlier cases than occur in an average or typical situation. Even if these firms may be outliers, the approach taken in this study is that it is also important to remember that outliers are particularly informative.

${ }^{12}$ In 1993, SAB miller was invited by the Tanzanian government as its first privatisation partner to become the strategic shareholder in TB with management control. The shareholding structure of the company stands as follows; SAB plc 66 per cent, International Finance Corporation (IFC) 8.79 per cent, the Government of Tanzania 5 per cent, Privatisation Trust 10 per cent and the general public owns 10.17 per cent.

${ }^{13}$ TB has also a controlling interest in Tanzania Distilleries and Darbrew. Tanzania Distilleries manufactures and distributes prominent local spirits in Tanzania as well as imported wines and spirits. Darbrew produces and sells traditional local beer.

${ }^{14}$ Beer consumption per capita levels in Tanzania are 6 litres compared to 13 in Angola, 32 in Botswana.

${ }^{15}$ For example, productivity levels in TB's main brewery in Dar were very low by international standards, 316 $\mathrm{hl} /$ capita compared to the industrial standard of 5,400. One of the reasons for the productive inefficiency in the pre-privatisation period was the operating bottling lines, commissioned in 1991 based on second hand technology and were never fully utilised to their maximum output, because of extensive breakdown which frequently resulted in serious delayed production runs. TB's production efficiency was hindered by inferior 
quality of intermediate inputs such as barley and glass bottles, obsolete refrigeration system and lack of quality assurance. Filled bottles often contained too much air, reducing the shelf life of the beer and hence provoking customer complaints and lost market share.

${ }^{16}$ More recently around $\$ 4$ million have been invested in new bottling and canning facilities aimed to increase productive efficiency, introduce product innovation and secure quality. Packaging lines have been fitted with state-of-the-art automated bottle inspectors to avoid infiltration in production. This is the first such facility commissioned in East Africa and is enabling TB to increase consumer choice in the 'beer take away as well as increase export orientation. Exports of Castle in cans has been directed to Uganda.

${ }^{17}$ For example, as a result of investing in new plant and equipment, the brewing process now has a more accurate yeast and oxygen dosing process regardless of production flows, .providing greater uniformity in product blends and extensive cost reduction. The result is a complete and well documented process line designed to maintain the characteristics of the beer and meet the quality requirements.

${ }^{18}$ Efficiency is a measure of the actual volume produced compared to the theoretical volume over a certain period of time. In the case of factory efficiency, it applies to the whole brewery and in the case of machine efficiency to an individual packaging line. TB has achieved 70 per cent factory efficiency (compared to 50 per cent levels in the early 1990s) which compares to world class industrial standards and the efficiency in 'sister' affiliates in the MNE network.

${ }^{19} \mathrm{~TB}$ has to comply with a rigorous, MNE group-wide approach to quality control and product safety. To ensure that quality is monitored and tracked, new product labelling systems such as the Julian Calendar Codes including brewing data (brewery name, production line, manufacturing date and time) and 'best before date' have been introduced use. This assists in the management of stocks and helps trace the origin in the event of quality enquiries.

${ }^{20}$ Improvements in the production process have led to a decrease in energy consumption. Effluent is managed upstream generally by removing a large proportion of the organic pollutants such as yeast and inorganic loading from the chemical cleaning processes. In addition, the recycling rate of bottle washing water has been increased, thereby reducing fresh water consumption requirements.

${ }^{21}$ For example, the Konyagi brand has been revamped and new brands introduced, permitting the company to acquire more than 10 per cent of the local market share and link up with international partners. Significant investment has been undertaken at Dar Brew revamping the quality of local brands such as Kibuku and Mwamba.

${ }^{22}$ The brand portfolio has been widened extensively to include the production and distribution of brands such as SAB Miller's flagship brand Castle Lager, Castle Milk Stout, Redds Premium Cold under licence to the parent company. Safari Lager is the market leader. Kilimanjaro Premium and Safari Lager represent the leading mainstream clear brands commanding 84 per cent of clear beer volumes. More brands are being produced in the $340 \mathrm{ml}$ can which has reduced the reliance on imports and created the opportunity of pursuing exports. TB was able to embark on the export of its brands to the neighbouring countries on a sustainable basis. Castle Lager is the leading export brand, with Redds following. No local brands are successfully exported. Following the acquisition of Kibo Breweries, the Company now also manufactures and distributes certain East African Breweries (EABL) brands under license.

${ }^{23}$ Care for human resources has extended to other economic and social considerations such as provision of good food from the canteen, better medical services and attractive remuneration. As well as providing in-house training, selected employees are sent to SAB's Training Institute in South Africa for advanced managerial education and technical development. The in-house training department organizes various short courses as part of departmental on-the-job training. The policy adopted regarding management development in TB is to improve skills of staff in activities related to the functions of the company. TB prefers to employ already qualified staff who need only to be introduced to the company's working methods.

${ }^{24}$ Due to the political sensitivity of downsizing, the company has undertaken the process in two main stages, namely, voluntary and forced staff reduction.

${ }^{25}$ In some cases departments were reduced to sections under one main department. This represents a continuous process that aims to ensure that structures contribute to achieving the desired goals.

${ }^{26}$ To this end, tailor-specific training courses are given by equipment suppliers in both process and automation technology and these are designed to extend the skills base and increase the specialist knowledge. Such courses are offered either on-site or at supplier premises abroad. Time allocated to training is an average of 3.2 days per employee per annum. Within the MNE parent human resource development categorization, TB has moved from a lower category of 'emerging' to 'developed' over a five year period.

${ }^{27}$ The main area of concern has been to lead staff to understand the objectives of the company, their internal systems covering accounts, commercial, human resource and technical areas. The first step in management development by the new investors has been to expose staff to parent company systems that make reporting and monitoring easier. 
${ }^{28}$ A market-related salary system has also being introduced as a way of retaining staff.

${ }^{29} \mathrm{~TB}$ cost of beer/hecto litre stands at US\$10 compared to 15 for its main international competitors. For TB, low cost maintenance is important in the context of avoiding unnecessary fluctuations in price so that more consumers can afford despite the fact that the economic situation in Tanzania changed little if at all between the share purchase and the time of writing.

30 This is measured according the quality standards and 'defect' in the production process of beer and end product. SABMiller Africa and Asia introduced an inter-brewery competition in October 2001, in which all production facilities are benchmarked and scored against a set of technical measures to determine a 'Brewery of the Year'. In the first round of this competition, TB through its Arusha Brewery attained the second highest score for producing the best quality beer among all of SAB's international breweries, including those in Europe and Asia.

${ }^{31}$ The 9 units are; leaf, manufacturing, sales and marketing, human resources, finance, legal, corporate affairs, company services and exports.

32 TCC produces three main types of cigarette blends, namely American, Dark Fired and Virginia.

${ }^{33}$ These segments can be broadly categorised as low, value, medium and premium brand cigarettes.

${ }^{34}$ This was also the first American blend cigarette to be ever produced in East Africa region.

${ }^{35}$ Employment was not drastically cut, since there was an element of natural wastage and re-deployment in factory activities.

${ }^{36}$ There are now manuals, code of conducts, jobs are defined and described systematically. In case of stoppages, the time, shift, date and personnel involved and which type of machinery will be immediately evaluated.

${ }^{37}$ The entire picture of the operations of TCC is known by directors by the first week of every month. If there are any operational problems, decisions are taken immediately.

38 As a result of this linkage, KIOO Ltd has increased production volumes and invested considerably in its technological capabilities. Spearheaded by the success in supplying TB, the company stepped up its export sales. For example, following the supplier agreement in Tanzania, the company entered into a similar supplier agreement with a SAB affiliate in Uganda.

${ }^{39}$ Tanzania boasts a well established tobacco farming industry based mainly in the Tabora, Iringa and Ruvuma regions. It is the fourth major export crop after cashews, coffee and cotton. Tobacco production in 2001 was estimated at 30,000 tons. The JT group is jointly the largest buyer of Tanzania tobacco with TCC using around 2,000 tons annually for domestic manufacture of cigarettes and a further 2,200 tons being exported to other plants worldwide. The tobacco industry accounts for about 10 per cent of the value of agricultural cash crop exports of Tanzania and employs more than 200,000 families. The cigarette industry generates over US $\$ 40$ million in tax revenues in 2001, equivalent to about 6 per cent of the Government's recurrent revenues in 2001.

${ }^{40}$ There are certain constraints to these backward linkages. In Tanzania, tobacco yields are low (between 600$1,500 \mathrm{~kg}$ per hectare compared to 1,800 kg/ha in Malawi and 2,000 kg in Zimbabwe), stemming from inadequate production inputs, poor extension services and research, poor crop husbandry and high level of post harvest losses.

${ }^{41}$ The PSI brings together the major MNE affiliates in Tanzania from a number of important sectors, such as mining, industry and manufacturing, including TB and TCC.

${ }^{42}$ Anecdotal evidence suggests that both TB and TCC have entered into technical collaborative relationships with their suppliers in a bid to control the quality, reliability and timely supply of inputs. These collaborations have also led to considerable technological capability development on the part of the suppliers which could draw on the resources, expertise and support of the foreign affiliates.

${ }^{43}$ Although it must be said that in the case of TCC, this linkage is an indirect one since, foreign affiliates as tobacco processors act as middlemen between TCC and the farmers.

${ }^{44}$ For these local economic agents, primarily farmers, the linkages with other foreign affiliates represent notable development since either these vertical linkages did not exist before privatization or were not so well developed.

${ }^{45}$ Lim and Pang (1982) caution on the developmental impact of linkage creation. They argue that affiliate local sourcing may increase domestic value-added and incomes, but by less than the value and proportion of local input purchases suggest, since locally procured items themselves are most likely to be imported or embody a large import content. 